\title{
The Competency of Inclusive Elementary School Teacher in Utilizing Technology-Based Learning Media
}

\author{
Ayu Rahayu ${ }^{1}$, Dinar Westri Andini' ${ }^{2}$ C. Asri Budiningsih ${ }^{3}$, Mumpuniarti $^{4}$ \\ \{ayu.rahayu@ustjogja.ac.id ${ }^{1}$, dinarandini7@gmail.com², asri_budi@yahoo.co.id ${ }^{3}$, \\ mumpuni@uny.ac.id $\left.{ }^{4}\right\}$ \\ Universitas Sarjanawiyata Tamansiswa, Yogyakarta, Indonesia ${ }^{12}$ \\ Universitas Negeri Yogyakarta, Yogyakarta, Indonesia ${ }^{34}$
}

\begin{abstract}
This study aims to determine the competence of inclusive elementary school teachers in utilizing media based on technology in terms of planning of learning based on information and communication technology. The research method is descriptive quantitative. The research was carried out in the province particular region of Yogyakarta. The subjects consisted of 138 teachers of SD Inklusi located in Bantul, Gunungkidul, Sleman, Kulonprogo and Yogyakarta. The research instrument using the test is completed with observation and interview. The results showed that the ability of elementary school teachers Inclusion in planning learning based on information and communication technology (ICT) of $38.65 \%$. The highest value is the ability to plan ICTbased learning activities by $54.35 \%$. Furthermore, the ability to prepare ICT-based materials reaches a value of $32.61 \%$. While the lowest cost is the ability to plan ICTbased e-learning media of $28.98 \%$. The result of the study illustrates that the learning done in the classroom is still conventional and teacher-centered with the dominance of the lecture method and has not done the development of ICT-based learning media capable of accommodating all the diversity and also raises the participation of all students in the class.
\end{abstract}

Keywords: competency, inclusive elementary school teacher, technology, learning media

\section{Introduction}

The paradigm of inclusive education becomes a solution in the distribution of rights in getting a decent education for all people. The presence of inclusive education is also a strategic effort in completing 9-year compulsory education and access to education for all children without exception, eliminating the label of discrimination including children who have special needs that will change the attitude of the community itself to the view of children with this particular need [1].

The hope of implementing an open, inclusive education of diversity and being sociable for all the differences will bring about an inclusive society. This strongly supports the ultimate goal of knowledge that in the end, everyone should be able to live side by side with one another, according to a statement revealed by UNICEF "learning to live together."

Indonesia since 2000 has developed inclusive education, and for decades the government has made regulations by adopting policies and supporting the implementation of inclusive 
education in their respective regions. Not apart from the special region of Yogyakarta that has declared to be an inclusive city and in 2013, the enforcement of inclusive education in the special region of Yogyakarta is further strengthened by the issuance regulation of the governor of the special region of Yogyakarta number 21 of 2013. In chapter 3, verse 1 states that every educational unit shall receive special needs students. This means that all schools in the special region of Yogyakarta should not reject children and must accept anyone who will enroll in the school[2].

The regulation requires all schools to be open to all children regardless of their background. Schools should be able to develop and provide facilities to support the implementation of inclusive education and also develop teachers' skills in teaching in diverse classes. The diversity in the classroom is more complicated, where students at the school have a variety of characteristics both in learning needs, their different learning abilities and ways[3].

The concept and practice of inclusive education itself refer to international documents in the Salamanca Statement and Framework for Action on Special Needs Education[4]. The report states that there are two fundamental principles in the practice of inclusive education that all children should learn together regardless of the difficulties or differences that exist in themselves. Inclusive schools should recognize and respond to the different needs of their students, accommodate the different styles and speed of learning, and ensure quality education to all students through the development of appropriate curricula, good organization, proper teaching strategy selection, utilization sourcing well, and raising partnerships with surrounding communities. In addition, accommodation and learning modifications are needed as well as providing various media as a means of learning to eliminate child learning barriers and solely concerned with child welfare.

Classroom teachers can provide technology-based learning media to provide opportunities for all students to learn in the classroom. By using technology, children with special needs can also access and learn together with other friends in the class. If teachers only use "textbooks," then students with special needs will have difficulty in following the lesson. One example of media technology such as digital media can be a solution and a versatile strength because the material can be given in the form of images, sound, video or a combination of formats, so it is constructive for children with special needs to understand the material given[4][1].

Based on the fundamental principles in the practice of inclusive education that must eliminate the learning barriers of students and realize the active participation of all students in the classroom, it is the necessary competence of teachers who are able to develop innovative learning one by using technology to accommodate the diversity of students in the class. Students who have special needs or who should not be able to learn together in the classroom. Teachers must be able to make learning innovations and provide various media in support of the success of learning in the school [5][6].

\section{Method}

This research uses quantitative descriptive method. The research will illustrate the competence of elementary school teachers (inclusion) in information and communication technology based on three aspects of ability: (1) planning ICT-based materials, (2) designing ICT-based learning activities, and (3) designing ICT-based e-learning media The research subjects are elementary school teachers of inclusion in the province of Yogyakarta Special Region (DIY). Elementary school is chosen purposively by considering the status of public / private elementary school, SD location near / far from regency / city center, and participation in training which often given by other institution education office related to inclusive education. Based on this matter selected 138 teachers of inclusive elementary school as 
research subject. The research instrument is a competency test in the form of multiple choice questions with five answer choices. Data analysis is done descriptively with percentage.

\section{Results and Discussion}

The data obtained shows that the ability of elementary school teachers of Inclusion in designing learning based on information and communication technology amounted to $38.65 \%$. This can be seen in Table 1 . The highest value is the ability to plan ICT-based learning activities by $54.35 \%$. Furthermore, the ability to plan ICT-based materials reaches a value of $32.61 \%$. While the lowest value is the ability to plan ICT-based e-learning media of $28.98 \%$.

Table 1. Ability of elementary school teachers Inclusion in planning computer-assisted learning

\begin{tabular}{llc}
\hline No & \multicolumn{1}{c}{ Type of ability } & Precentage \\
\hline 1 & Planning for ICT-based materials & $32,61 \%$ \\
2 & Planning ICT-based learning activities & $54,35 \%$ \\
3 & Planning ICT-based learning media & $28,98 \%$ \\
\hline Average & $38,65 \%$ \\
\hline
\end{tabular}


The ability to plan ICT-based activities and feedback materials is very important for teachers. This shows the content and pedagogic ability of the teacher (PCK). PCK is a declarative knowledge of content and pedagogy that is poured into the planning of materials and learning activities[7]. In accordance with the Law of the Republic of Indonesia Number 20 Year 2003 on National Education System Article 39 paragraph 2 states that educators, especially teachers are professionals in charge of planning and implementing the learning process and assess the learning outcomes[8]. Therefore, in order to carry out its duties to plan and implement the learning process and assess the results of learning well, a teacher must have knowledge about the content of the subject matter (content) and have the ability to teach (pedagogy)[1].

The ability to plan ICT-based e-learning activities is very important for teachers because of the content and pedagogic skills of teachers (PCK). Based on the research results, this ability will be varied for each teacher. Figure 1 shows the percentage of inclusive elementary school teachers' ability to plan ICT-based leverage activities.

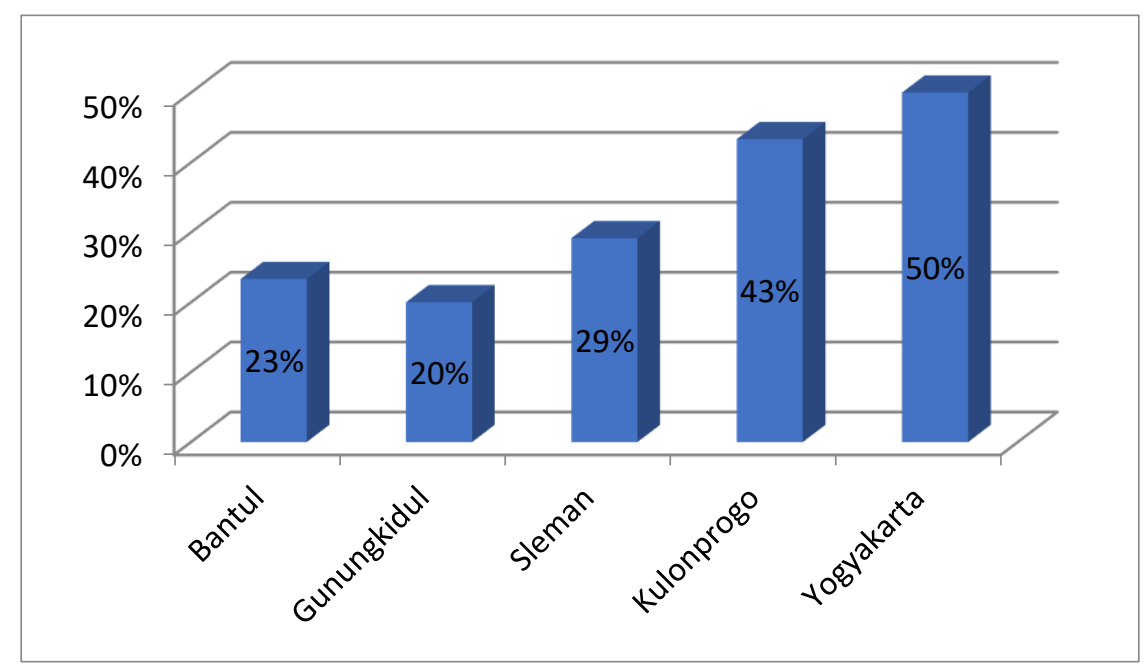

Fig 1.The ability of elementary school teachers in inclusion in planning ICT-based learning activities

The ability to plan ICT-based materials also shows how much teacher and pedagogic content (PCK) is. Figure 2 shows the percentage of inclusive elementary school teachers' capacity in each district and city in Yogyakarta in planning ICT-based feedback materials. 


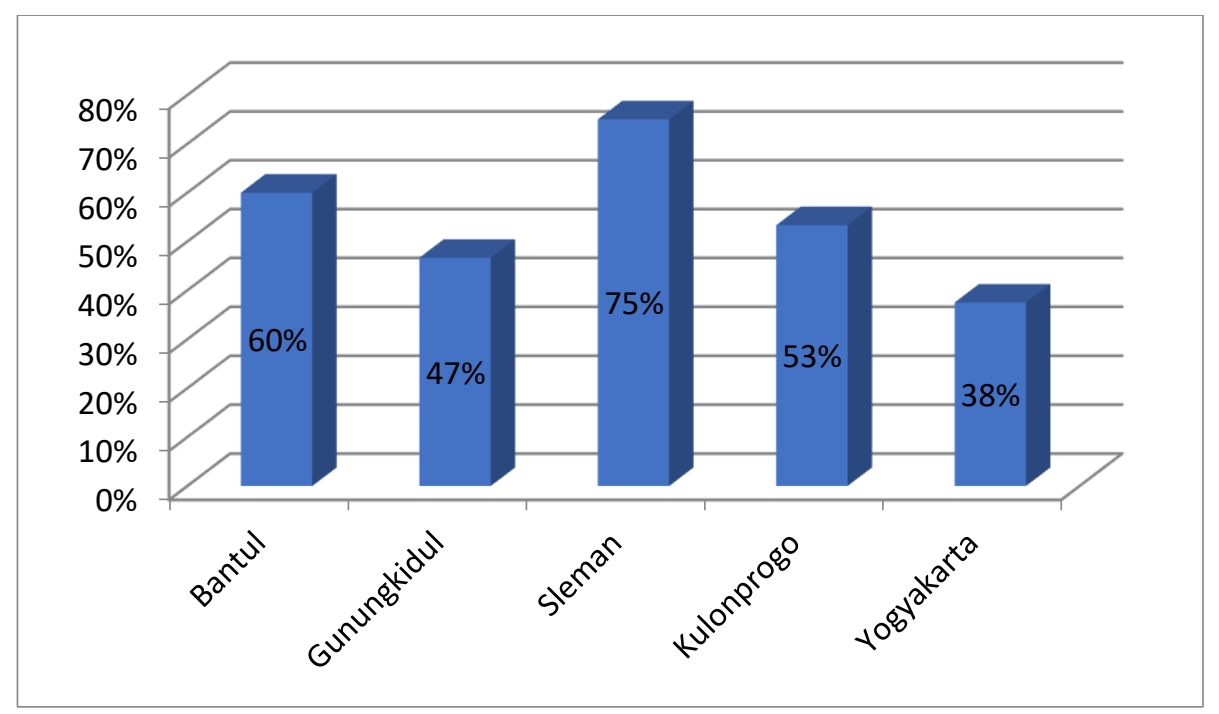

Fig 2.The ability of elementary school teachers in inclusion in planning ICT-based learning materials

The ability to plan ICT-based e-learning media also varies for each teacher. The highest value is owned by elementary school teachers inclusion in the city of Yogyakarta by $42 \%$. After that Sleman 33\%, Bantul and Kulonprogo 27\% and Gunungkidul 20\%.

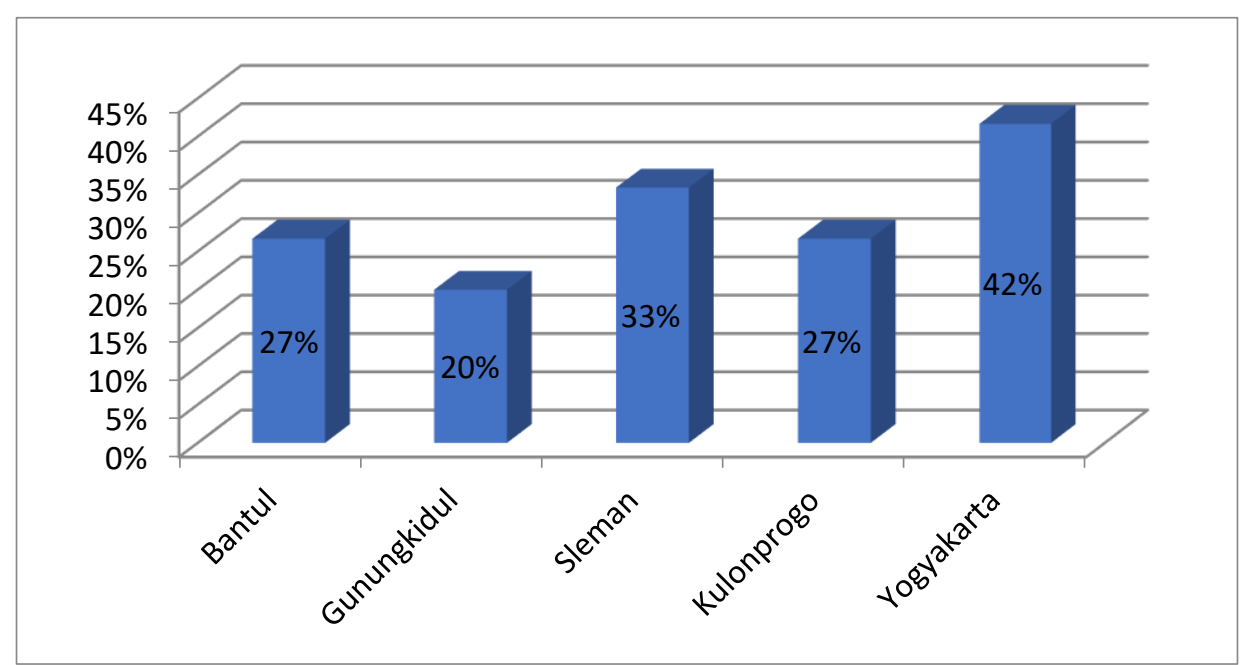

Gambar 3.The ability of elementary school teachers in inclusion in planning ICT-based learning media 


\section{Conclussion}

The results showed that the ability of elementary school teachers Inclusion in planning learning based on information and communication technology (ICT) of 38.65\%. The highest value is the ability to plan ICT-based learning activities by $54.35 \%$. Furthermore, the ability to plan ICT-based materials reaches a value of $32.61 \%$. While the lowest value is the ability to plan ICT-based e-learning media of $28.98 \%$. The result of the study illustrates that the learning done in the classroom is still conventional and centered on the teacher with the dominance of the lecture method and has not done the development of ICT-based learning media capable of accommodating all the diversity and also raises the participation of all students in the class.

\section{References}

[1] P. Pendidikan and L. Biasa, “( Konsep, Kebijakan, dan Implementasinya dalam,” pp. 1-15, 2009.

[2] S. Burgstahler, "Universal Design: Implication for Computing Education," ACM.Transaction Comput. Educ., vol. 11(3), pp. 10-17, 2011.

[3] "The Salamanca Statement and Framework for Action on Special Needs Education.," 2014.

[4] S. Harris, K.R. \& Graham, Universal Design for Learning in The Classroom Practical Application. New York: The Guilford Press, 2012.

[5] H. Bourke-Taylor, C. Cotter, L. Johnson, and A. Lalor, "Belonging, school support and communication: Essential aspects of school success for students with cerebral palsy in mainstream schools," Teach. Teach. Educ., vol. 70, pp. 153-164, 2018.

[6] G. Ball, D., Thames, M. and Phelps, "Content knowledge for teaching: what make it special.," J. Teach. Educ., vol. 59 (5), pp. 389-407, 2008.

[7] Law of the Republic of Indonesia Number 20, Year 2003, on National Education System. .

[8] A. Rahayu, "Development of SSP Based Learning Cycle Model To Improve Process Skills And Understanding Physical Concepts.," J. Sci. Educ. UNIMUS., 2014. 